Wiraraja Medika: Jurnal Kesehatan
https://www.ejournalwiraraja.com/index.php/FIK
2088-415x (Print) |2685-9998 (online)

\title{
Pelaksanaan Self Management terhadap Perilaku Perawatan Diri pada Pasien Gagal Jantung di Desa Plesungan
}

\author{
Saelan $^{1 *}$, Dzurriyatun Toyyibah², Galih Setia Adi ${ }^{3}$, Budi Prasetyo ${ }^{4}$ \\ ${ }^{1,2,3}$ Prodi Keperawatan Program Sarjana, FIK, Universitas Kusuma Husada Surakarta \\ ${ }^{4}$ Prodi Promosi Kesehatan Program sarjana terapan, FIK, Universitas Kusuma husada \\ Surakarta \\ saelanelan@gmail.com ${ }^{1 *}$, thoyyibah.za@gmail.com², galihkh88@gmail.com³, \\ asli.budi.prasetyo@gmail.com ${ }^{4}$ \\ *Corresponding author
}

\begin{tabular}{l}
\hline Informasi artikel \\
\hline Sejarah artikel: \\
Received: $13-07-2021$ \\
Revised: $22-11-2021$ \\
Accepted:30-11-2021 \\
\hline Kata kunci: \\
Gagal Jantung \\
Perilaku Perawatan Diri \\
Self Management
\end{tabular}
\begin{abstract}
ABSTRAK
Penyakit Gagal jantungberesiko mengalami kekambuhan yang disebabkan karena kurangnya perawatan diri.Sebagian besar kekambuhan gagal jantung terjadi karena pasien tidak melaksanakan perawatan mandiri, misalnya tidak melaksanakan terapi pengobatan dengan tepat, melanggar pembatasan diet, tidak mematuhi tindak lanjut medis, melakukan aktivitas fisik yang berlebihan, dan tidak dapat mengenali gejala kekambuhan.Tujuan penelitian ini untuk Mengetahui pengaruh sebelum dan sesudah pelaksanaan Self Management terhadap perilaku perawatan diri pasien gagal jantung kongestif di desa Plesungan dengan memberikan edukasi dan lembar monitoring pelaksanaan self management. Jenis penelitian ini adalah kuasi eksperimen, denganpre dan post test design group. Populasi penelitian ini adalah semua pasien dengan riwayatpenyakit gagal jantung di Desa Plesungan. Sampel penelitian ini adalah responden dengan riwayat penyakit gagal jantung kongestif dengan metodeconsecutive sampling sejumlah 18 responden. Metode penelitian dengan uji paired sample t-tes dengan confidence interval 95\%. Hasil analisis univariat didapatkan perawatan diri sebelum pemberian self management ada 7 yang adekuat dan 11 yang tidak adekuat, sedangkan setelah diberikan intervensi didapatkan 15 adekuat dan 3 tidak adekuat, sedangkan hasil analisis bivariat $p$ value 0,011 atau $\mathrm{p}<0,05$, maka ada pengaruh pemberian self management terhadap perilaku perawatan diri pada pasien gagal jantung kongestif. Kesimpulan self management terhadap perilaku perawatan diri pada pasien gagal jantung kongestif di Plesungan, saran bagi peneliti selanjutnya untuk meneliti tentang management kebutuhan diet yang tepat untuk penyakit gagal jantung.
\end{abstract}

Key word:

Heart failure

Self-Care Behavior

Self Management

\section{ABSTRACT}

Heart failure is a major problem in the field of cardiology with the increasing number of sufferers and incidence of re-treatment as well as death and disability. The aimisto determine the effect before and after the implementation of Self Management on the self-care behavior of patients with congestive heart failure in Plesungan Village. This type of research is a quasi-experimental, with pre and post control group tests. The study population was all patients with heart failure in heart disease in Plesungan Village. The sample in this study were 18 respondents with a history of congestive heart failure by means of consecutive sampling. The research method used was paired samples t-test with a 95\% confidence interval. The results of univariate analysis showed that 7 self-care before selfmanagement was adequate and 11 were inadequate, while after intervention it was found that 15 were adequate and 3 were inadequate, while the results of bivariate analysis were $p$ value 0.011 or $p<0.05$, so there was an effect of giving self management of self-care behavior in patients with congestive heart failure. Conclusion of self-management on self-care behavior in patients with congestive heart failure in Plesungan, suggestion for the next researchers to investigate the need for proper diet for heart failure disease. 


\section{PENDAHULUAN}

Gagal jantung merupakan masalah kesehatan yang progresif dengan angka mortalitas dan morbiditas yang tinggi di negara maju maupun negara berkembang seperti Indonesia. Keadaan tersebut perlu adanya penanganan lebih lanjut pada gagal jantung. WHO (2016), mencatat 17,5 juta orang di dunia meninggal akibat gangguan kardiovaskular. Lebih dari $75 \%$ penderita kardiovaskular terjadi di negaranegara berpenghasilan rendah dan menengah, dan $80 \%$ kematian kardiovaskuler disebabkan oleh serangan jantung dan stroke. Di wilayah Asia Tenggara, Indonesia termasuk kelompok dengan jumlah kejadian tertinggi yaitu 371 per 100.000 orang, lebih tinggi dibandingkan Timur Leste sebanyak 347 per 100.000 orang dan jauh lebih tinggi dibandingkan Thailand yang hanya 184 per $\quad 100.000$ orang. Data dari Riset Kesehatan Dasar (Riskesdas) Kementrian Kesehatan Indonesia pada tahun 2018, prevalensi penyakit gagal jantung di Indonesia berdasarkan diagnosis dokter diperkirakan sebesar 1,5\% atau diperkirakan sekitar 29.550 orang.(Aria, 2014.).

Gagal jantung menjadi masalah utama dalam bidang kardiologi karena bertambahnya jumlah penderita dan kejadian rawat ulang serta kematian dan kecacatan. Penyebab meningkatnya masalah gagal jantung adalah: (1) Keberhasilan penanganan serangan akut miokard infark yang berhasil menyelamatkan nyawa namun kecacatannya menyebabkan gagal jantung. (2) Bertambahnya jumlah orang yang mencapai usia lanjut sedangkan pada usia lanjut akan terjadi gagal jantung karena perjalanan usia. (3) Masih tingginya kejadian infeksi di Indonesia yang dapat menyebabkan penyakit jantung reumatik pasca infeksi Streptococcus beta hemolitikus, infeksi virus yang menyebabkan miokarditis, infeksi yang menyebabkan endokarditis serta tuberkulosis yang menyebabkan pericarditis tuberkulosa. (4) Masih seringnya ditemukan faktor faktor risiko penyakit jantung koroner seperti banyaknya perokok, diabetes, hiperkolesterolemia, hipertensi dan obesitas.. Acute Decompensated Heart failure Registry adalah suatu pendataan international menggunakan web yang mendata pasien dengan acute decompensated heart failure yang masuk dan dirawat di unit gawat darurat (Perhimpunan Dokter Spesialis Kardiovaskular Indonesia (PERKI), 2015).

Gejala yang timbul akibat perubahan struktur dan fungsi jantung akan berdampak secara langsung pada status fungsional pasien itu sendiri. Keterbatasan fungsional menjadi suatu hal yang sering terjadi pada pasien heart failure. Ketidakmampuan pasien heart failure untuk beradaptasi terhadap penyakitnya termasuk di dalamnya mengenal secara dini gejala penyakit (seperti sesak nafas, intoleransi aktivitas dan kelelahan) akan mempengaruhi kehidupan yang dijalaninya setiap hari (Djärv et al., 2012).

Self management merupakan kemampuan pasien CHF dalam mengelola dirinya, ini dapat ditingkatkan dengan edukasi dari perawat, pasien CHF harus mempunyai pengetahuan tentang penyakit yang dialaminya, bagaimana cara pencegahan timbulnya gejala dan apa yang bisa dilakukan pasien CHF jika gejala muncul, dengan Self management yang baik maka pasien CHF akan mempunyai motivasi dalam penanganan penyakitnya. Elemen inti dari panduan managemen CHF adalah monitoring secara teratur oleh klinisi, pengontrolan faktor pencetus, edukasi dan kerjasama antara klinisi dan pasien. Perawatan diri pada Perawatan diri merupakan proses pengambilan keputusan naturalistik di mana orang terlibat untuk tujuan menjaga kesehatan dan mengelola penyakit akut dan kronis(Riegel et al., 2017).

Misi dan visi American
HeartAssociation untuk membangun hidup yang lebih sehat, bebas dari penyakit kardiovaskular dan stroke. Bukti yang mendukung perilaku perawatan diri tertentu seperti diet dan olahraga, hambatan perawatan diri, dan efektivitas perawatan diri dalam meningkatkan hasil ditinjau, seperti bukti yang mendukung berbagai pendekatan individu, berbasis keluarga, dan berbasis komunitas untuk meningkatkan perawatan diri. Meskipun ada banyak perbedaan dalam hubungan antara perawatan diri dan hasil, ada bukti kuat bahwa perawatan diri efektif dalam mencapai tujuan rencana perawatan dan tidak dapat diabaikan. Dengan demikian, penekanan yang lebih besar harus ditempatkan pada perawatan diri dalam pedoman berbasis bukti.(Riegel et al., 2017).

Hasil penelitian menunjukkan adanya penyakit penyerta berhubungan dengan rendahnya perilaku dalam dimensi 
kepercayaan diri. Intervensi dengan metode khusus dapat dilakukan untuk meningkatkan kepercayaan diri pada pasien dengan penyakit penyerta. Dalam dimensi pengelolaan dan pemeliharaan tidak ada satupun faktor sosiodemografi yang berhub- ungan dengan perilaku perawatan diri pada 2 dimensi tersebut(Prihatiningsih \& Sudyasih, Tiwi, 2018).

Manajemendiri yang baik pada pasien pada gagal jantung kronis (CHF) dapat didefinisikan sebagai "aktivitas sehari-hari yang menjaga stabilitas klinis". Pasien wajib memantau gejala, mematuhi pengobatan, diet dan rejimen olahraga dan mengelola gejala dengan mengenali perubahan dan merespons dengan menyesuaikan perilaku atau dengan mencari bantuan yang sesuai. Manajemen mandiri pasien dikaitkan dengan penurunan risiko kematian dan lebih sedikit masuk rumah sakit; namun, ada sedikit kepastian terkait dengan manfaat dari beberapa aspek perawatan diri, seperti pilihan gaya hidup dan pembatasan cairan. Manajemen diri di CHF biasanya melibatkan adaptasi perilaku. Pasien mungkin perlu mempelajari perilaku baru, seperti mempelajari cara memantau dan mengelola gejala dan rejimen medis yang kompleks. Pasien mungkin juga perlu menghindari atau berhenti merokok, beradaptasi (misalnya membatasi asupan natrium, kolesterol dan cairan mereka) dan mempertahankan (misalnya berolahraga secara teratur). Meskipun target telah direkomendasikan untuk praktik manajemen CHF terbaik (seperti membatasi cairan hingga 1,5 liter per hari dan untuk memantau perubahan berat badan $>2 \mathrm{~kg}$ selama tiga hari), target ini perlu disesuaikan dengan gejala pasien dan profil status penyakit dan pengaturan ulang. secara teratur. Dari perspektif pasien, hal ini meningkatkan kompleksitas manajemen diri dan meningkatkan tuntutan kognitif, perilaku dan motivasi(Toukhsati et al., 2015).

Hasil penelitian menurut (Cui et al., 2019) dengan judul Program pendidikan kesehatan terhadap peningkatan keterampilan manajemen diri dan kejadian rawat ulangpada pasien gagal jantung kronis di dapatkan skor rata-rata kepatuhan pengobatan, modifikasi diet, dukungan sosial dan kontrol gejala pada kelompok intervensi lebih tinggi dibandingkan pada kelompok kontrol pada akhir penelitian ( $p$
$<0,01)$. Tingkat masuk kembali untuk HF pada kelompok intervensi dan kontrol adalah 10,4\% dan 27,1\%, masing-masing ( $\mathrm{p}=$ 0,036).Tenaga kesehatan yang profesional dalam merawat pasien gagal jantung harus dapatmengetahui masalah yang muncul pada pasien. Edukasi manajemen perawatan diri yang bertujuan untuk memberikan saran agar meningkatkan kepatuhan terhadap strategi manajemen diri, meningkatkan kualitas hidup, dan menunjukkan manfaat untuk mengurangi kejadian rawat inap ulang dan kematian (Lainscak et al., 2011).

\section{METODE PENELITIAN}

Penelitian ini adalah quasi eksperiment dengan desain penelitian adalah pre dan post tes with design group. Pada desain ini terdapat kelompok perlakuan yang diberikan pertanyaan tentang self managemant. Sebelum perlakuan, diberikan self management dalam meningkatkan perilaku hidup sehat pasien gagal jantung, kemudian diberikan intervensi self management dalam bentuk edukasi dan contoh kegiatan pencegahan gagal jantung kemuadian diberikan lembar ceklis untuk evaluasi kegiatan self managemen selama 4 minggu, kemudian dilakukan kembali pengukuran pada waktu periksa berikutnya pada pengukuran perilaku self management. Populasi penelitian ini adalah semua pasien gagal jantung di desa Plesungan, sampel dalam penelitian ini menggunakan teknik consecutive sampling, ditentukan sampel sebesar 18 responden dengan criteria inklusi Pasien post gagal jantung menjalani rawat jalan di Desa Plesungan, pasien didampingi oleh keluarganya, pernah dirawat di rumah sakit dengan gagal jantung kongestive, bisa membaca dan menulis. Penelitian dilakukan pada bulan April - Agustus 2020 di desa Plesungan. Alat ukur yang digunakan yaitu alat ukur perilaku yang sudah baku yaitu self care of heartfailure index (SCHFI). Uji normalitas dilakukan untuk mengetahui apakah distribusi data yang di dapatkan mengikuti atau mendekati hukum sebaran normal baku dari Gauss. Peneliti menggunakan uji Shapiro-Wilk dengan kriteria sampel kurang dari 50 menggunakan komputerisasi. Setelah dilakukan uji normalitas langkah selanjutnya adalah melakukan uji paired samples t-tes dengan confidence interval 95\% 
HASIL DAN PEMBAHASAN

Tabel 1. Karakteristik Responden berdasarkan Umur

\begin{tabular}{lllll}
\hline Karakteristik & $\mathrm{N}$ & Min & Max & Mean \\
\hline Usia & 18 & 41 & 77 & 59,33 \\
\hline $\begin{array}{l}\text { Jenis } \\
\text { Kelamin }\end{array}$ & $\mathrm{N}$ & $\%$ & - & - \\
\hline Laki- laki & 8 & $44,4 \%$ & - & - \\
\hline Perempuan & 10 & $55,6 \%$ & - & - \\
\hline
\end{tabular}

Karakteristik responden berdasarkan usia, rata rata usia responden 59,33 tahun, usia terendah 41 tahun, usia tertinggi 59,33 tahun. Usia merupakan faktor resiko terjadinya penyakit gagal jantung karenanya terjadinya penurunan fungsi tubuh. Menurut penelitian yang dilakukan oleh (Harigustian et al., 2016)bahwa Kelompok usia terbanyak responden gagal jantung yang diteliti ialah kelompok 60-70 tahun dimana usia tersebut merupakan 50\% dari jumlah responden keseluruhan. Distribusi penyakit CHF atau CHF kongestif meningkat pada usia 40 tahun keatas. Hal ini berkaitan dengan proses menua yang menyebabkan peningkatan proses aterosklerosis pada pembuluh darah. Aterosklerosis menyebabkan terganggunya aliran darah ke organ jantung sehingga terjadi ketidakseimbangan antara kebutuhan oksigen miokardium dengan suplai oksigen.

Karakteristik responden berdasarkan jenis kelamin terdiri dari laki laki sejumlah $8(44,4 \%)$ dan perempuan sejumlah 10 (55,6\%). Pada jenis kelamin laki-laki berisiko besar mengalami penyakit jantung koroner dibandingkan dengan perempuan, karena perempuan mempunyai pelindung alami yaitu hormon estrogen. Pada laki-laki pertengahan tahun manula yaitu usia 40 tahun ke atas, kenaikan kadar kolesterol dalam darah mempunyai risiko yang tinggi untuk pembentukan penyakit jantung koroner karena di akibatkan oleh gaya hidup yang kurang sehat, olahraga yang kurang dan pola makan yang tidak sehat (Suherwin, 2018)

Tabel 2. Karakteristik Responden berdasarkan perawatan diri $(\mathrm{n}=\mathrm{I} 8)$

\begin{tabular}{ccccc}
\hline Variabel & Adekuat & (\%) & $\begin{array}{c}\text { Tidak } \\
\text { Adekuat }\end{array}$ & (\%) \\
\hline $\begin{array}{c}\text { Perawatan } \\
\text { diri_pre }\end{array}$ & 7 & $\begin{array}{c}38, \\
9\end{array}$ & 11 & 61,1 \\
\hline $\begin{array}{c}\text { Perawatan } \\
\text { diri_post }\end{array}$ & 15 & 83, & 3 & 16,7 \\
& & 3 & &
\end{tabular}

Hasil perawatan diri sebelum pemberian self management ada 7 yang adekuat dan 11 yang tidak adekuat, sedangkan setelah diberikan intervensi didapatkan 15 adekuat dan 3 tidak adekuat. Management perawatan mandiri dapat diartikan sebagai tindakan-tindakan yang bertujuan untuk dapat memperburuk kondisi dan mendeteksi gejala awal perburukan gagal jantung. Manajemen perawatan mandiri mempunyai peran penting dalam keberhasilan pengobatan gagal jantung dan dapat memberi dampak bermakna untuk perbaikan gejala gagal jantung, kapasitas fungsional, kualitas hidup, morbiditas, dan prognosis. Ketaatan pasien untuk berobat dapat mempengaruhi morbiditas, mortalitas dan kualitas hidup pasien. Berdasarkan literatur, hanya $20-60 \%$ pasien yang taat pada terapi farmakologi maupun nonfarmakologi(Perhimpunan Dokter Spesialis Kardiovaskular Indonesia (PERKI), 2015).

Manajemen diri pasien menjadi dasar untuk keberhasilan melakukan perawatan diri pada penderita CHF, Kecacatan pasien, beban penyakit dan dekompensasi merusak kepatuhan terhadap perilaku manajemen diri yang direkomendasikan dengan laporan bahwa hingga 60\% pasien tidak mematuhi rejimen pengobatan seperti yang ditentukan dan hingga 80\% tidak mematuhi rekomendasi gaya hidup. juga menemukan bahwa pasien cenderung mentolerir eksaserbasi gejala CHF mereka dan menunda mencari bantuan. Edukasi kesehatan, dukungan sosial dapat meningkatkan perilaku manajemen diri pasien. Teknik mengkonseptualisasikan manajemen diri pasien "dari intervensi individual, berbasis perilaku ke pendekatan yang berpusat pada komunitas dan jaringan.(Toukhsati et al., 2015).

Tabel. 3. pengaruh self management terhadap perawatan diri.

\begin{tabular}{lcc}
\hline Perawatan diri & $Z$ & P-Value \\
\hline Perawatan diri_post & $-2,530$ & 0,011 \\
Perawatan diri_pre & &
\end{tabular}

Berdasarkan Tabel 4 hasil $\mathrm{p}$ value 0,011 atau $\mathrm{p}<0,05$, maka H0 ditolak dan H1 diterima artinya ada pengaruh pemberian self management terhadap perilaku perawatan diri pada pasien gagal jantung kongestif di desa Plesungan.

Self management membutuhkan kesadaran yang tinggi karena terkait pola dan perilaku hidup. Kesadaran dalam 
memproses dan memperoleh informasi dengan baik dan intensif akan memberikan gambaran kondisi pasien yang berdampak pada kesehatannya. Pemberian self management program dapat meningkatkan tingkat koping pasien penyakit jantung koroner menjadi baik secara signifikan. Perbaikan juga terjadi pada niat dan kepatuhan berobat pasien penyakit jantung koroner di RSUD Jombang menjadi pada level baik (Mufarokhah et al., 2016).

Dalam dimensi pemeliharaan diri, lebih dari separuh perilaku masih perlu ditingkatkan yaitu perilaku menimbang berat badan setiap hari, berolah raga minimal 30 menit, perilaku mencegah atau menghindar dari sakit, mengu- rangi konsumsi garam saat diluar rumah, penggunaan alat bantu pengingat dan mengecek pembengkakan pada kaki. Hasil ini mengindi- kasikan perlunya perhatian dan upaya serius dari perawat maupun petugas kesehatan lainnya agar mampu meningkatkan perilaku perawatan diri yang lebih optimal (Prihatiningsih \& Sudyasih, Tiwi, 2018).

Setiap individu bertanggung jawab atas pribadinya. Perawat yang memiliki tugas melakukan pengelolaan pasien berkontribusi dalam kemandirian pasien, yang diidentikkan dengan perubahan perilaku pasien. Hal ini merupakan tantangan tersendiri yang membutuhkan dukungan dan waktu antarapasien dan perawat. Pasien sebagai individu membutuhkan dukungan untuk mengelola penyakit seefektif mungkin. Berbagai penelitian menunjukkan bahwa manajemen diri memiliki efek posistif dalam perawatan kesehatan dan meningkatkan kepuasan pasien (Warsito, 2018).

Hasil penelitian ini mendukung untuk meningkatkan perawatan diri pada penyakit jantung, sebagaimana hasil studi penelitian yang dilakukan oleh (Studi et al., 2020), dengan studi penelitian gambaran self management pada penderita gagal jantung di RS Universitas Sebelas Maret terbanyak mempunyai self management yang kurang baik sehingga perlu adanya edukasi secara langsung pada responden.

Faktor terkait pemeliharaan perawatan diri meliputi, dukungan sosial, kepercayaan perawatan diri, dan manajemen perawatan diri.Pada responden laki-laki, hubungan antara dukungan sosial dan pemeliharaan perawatan diri, dimeditasi oleh kepercayaan perawatan diri, sedangkan pada responden wanita hubungan antara pengetahuan tentang gagal jantung dan perawatan perawatan diri dimeditasi oleh manajemen perawatan diri. Pemeliharaan perawatan diri tidak memadai pada kedua jenis kelamin dengan gagal jantung kronis. Intervensi untuk meningkatkan dukungan sosial dan kepercayaan perawatan diri pada pasien laki-laki. Sedangkan pada pasien wanita dengan memperkuat pengetahuan tentang gagal jantung, manajemen perawatan diri dan kepercayaan perawatan diri dapat memfasilitasi pemeliharaan perawatan diri (Mei et al., 2019).

\section{KESIMPULAN}

Terdapat pengaruh pemberian self management pelaksanaan self management terhadap perilaku perawatan diri pada pasien gagal jantung kongestif di desa Plesungan. Perawatan diri pada pasien gagal jantung merupakan tugas setiap individu untuk bertanggung jawab atas pribadinya. Perawat yang memiliki tugas melakukan pengelolaan pasien dan berkontribusi dalam kemandirian pasiendengan perubahan perilaku pasien.

Simpulan ditulis secara singkat, padat dan jelas dalam satu paragraf, yang merupakan ringkasan dari hasil dan pembahasan serta menjawab tujuan dari penelitian/publikasi. Menekankan pada kebaharuan dari penemuan atau pengembangan.Apabila terdapat saran dari penelitian yang berkaitan dengan hasil penelitian untuk kegiatan praktis ataupun penelitian lanjutan berdasarkan hasil kebaharuan yang ditemukan dapat disampaikan secara singkat dan jelas pada akhir paragraf atau dapat membuat paragraf baru.

Saran bagi warga masyarakat diharapkan selalu mendukung program pencegahan penyakit jantung dengan perawatan diri yang baik, dan bagi peneliti selanjutnya diharapkan dapat mengembangkan penelitian dengan berbagai intervensi keperawatan untuk mencegah kekambuhan penyakit gagal jantung

DAFTAR PUSTAKA

Cui, X., Zhou, X., Ma, L. Le, Sun, T. W., Bishop, L., Gardiner, F. W., \& Wang, L. (2019). A Nurse-Led Structure Duration Program 
Improves Self-Management Skills and Reduces Hospital Readmissions in Patients With Chronic Heart Failure: a Randomized and Controlled Trial in China. Rural and Remote Health, 19(2). https://doi.org/10.22605/RRH5270

Destiawan Eko Utomo, Febi Ratnasari, Arfan Andrian, 2019.Kualitas Hidup Pasien Congestive Heart Failure. (2019). Kualitas Hidup Pasien Congestive Heart Failure. Jurnal Kesehatan, 8(2). https://doi.org/10.37048/kesehatan.v $8 \mathrm{i} 2.145$

Djärv, T., Wikman, A., \& Lagergren, P. (2012). Number and burden of cardiovascular diseases in relation to health-related quality of life in a cross-sectional population-based cohort study. BMJ Open, 2(5), 1-7. https://doi.org/10.1136/bmjopen2012-001554

Harigustian, Y., Dewi, A., \& Khoiriyati, A. (2016). Gambaran Karakteristik Pasien Gagal Jantung Usia 45 - 65 Tahun Di Rumah Sakit Pku Muhammadiyah Gamping Sleman. Indonesian Journal of Nursing Practices, 1(1), 55-60. https://doi.org/10.18196/ijnp.1152

Jantung, G., Di, K., \& Surakarta, K. (2017). GAMBARAN KUALITAS HIDUP PADA PASIEN GAGAL JANTUNG KONGESTIF DI KOTA SURAKARTA Disusun sebagai salah satu syarat menyelesaikan Program Studi Strata 1 pada Jurusan Keperawatan Fakultas Ilmu Kesehatan.

Lainscak, M., Blue, L., Clark, A. L., Dahlström, U., Dickstein, K., Ekman, I., McDonagh, T., McMurray, J. J., Ryder, M., Stewart, S., Strmberg, A., \& Jaarsma, T. (2011). Self-care management of heart failure: Practical recommendations from the patient care committee of the heart failure association of the European society of cardiology. European Journal of Heart Failure, 13(2), 115126.

https://doi.org/10.1093/eurjhf/hfq21 9

Mei, J., Tian, Y., Chai, X., \& Fan, X. (2019). Gender differences in self-care maintenance and its associations among patients with chronic heart failure. International Journal of Nursing Sciences, 6(1), 58-64. https://doi.org/10.1016/j.ijnss.2018.1 1.008

Mufarokhah, H., Putra, S. T., \& Dewi, Y. S. (2016). SELF MANAGEMENT PROGRAM
MENINGKATKAN KOPING, NIAT DAN KEPATUHAN BEROBAT PASIEN PJK (Self Management Programme Improve Coping, Intention, and Medication Adherence in Patients with Coronary Heart Disease). Jurnal Ners, 11(1), 5662. https://ejournal.unair.ac.id/JNERS/article/view /1902

Perhimpunan Dokter Spesialis Kardiovaskular Indonesia (PERKI), 2015.Pedoman Tatalaksana Gagal Jantung. (20151). Pedoman Tatalaksana Gagal Jantung. 1.

Prihatiningsih, D., \& Sudyasih, Tiwi, 2018. Perawatan Diri Pada Pasien Gagal Jantung. (2018). Perawatan Diri Pada Pasien Gagal Jantung. Jurnal Pendidikan Keperawatan Indonesia, 4(2).

https://doi.org/10.17509/jpki.v4i2.13 443

Riegel, B., Moser, D. K., Buck, H. G., VaughanDickson, V., B.Dunbar, S., Lee, C. S., Lennie, T. a., Lindenfeld, J. A., Mitchell, J. E., Treat-Jacobson, D. J., \& Webber, D. E. (2017). Self-care for the prevention and management of cardiovascular disease and stroke: A scientific statement for healthcare professionals from the American heart association. Journal of the American Heart Association, 6(9), 1-27. https://doi.org/10.1161/JAHA.117.00 6997

Studi, P., Keperawatan, I., Kesehatan, F. I., \& Surakarta, U. M. (2020). Gambaran self management pada pasien gagal jantung.

Suherwin. (2018). Hubungan Usia, Jenis Kelamin dan Riwayat Penyakit Dengan Kejadian Penyakit Jantung Koroner di Instalasi Gawat Darurat Rumah Sakit TK II dr. AK. Gani Palembang Tahun 2016. Aisyiyah Medika, 1, 89-97.

Toukhsati, S. R., Driscoll, A., \& Hare, David L, 2015. Patient Self-Management In Chronic Heart Failure - Establishing Concordance Between Guidelines And Practice. (2015). Patient SelfManagement In Chronic Heart Failure - Establishing Concordance Between Guidelines And Practice. Cardiac Failure Review, 1(2), 128. https://doi.org/10.15420/cfr.2015.1.2 .128

Wahyuni, Aria, 2014.Hubungan Self Care dan Motivasi dengan Kualitas Hidup 
Pasien Gagal Jantung Self-Care Motivation, and Q. of L. among P. with H. F., \& Kurnia, O. S. (2014). Hubungan Self Care dan Motivasi dengan Kualitas Hidup Pasien Gagal Jantung Self-Care , Motivation , and Quality of Life among
Patients with Heart Failure. Stikes Fort De Kock Bukittinggi, 2(Vol. 2), 108-116. Warsito, B. E. (2018). Peningkatkan kemampuan pasien dalam self manajemen. 6-10. 